Article - Agriculture, Agribusiness and Biotechnology

\title{
Endophytic Actinomycetes as Potential Producers of Hemicellulases and Related Enzymes for Plant Biomass Degradation
}

Diogo Robl ${ }^{1^{*}}$

https://orcid.org/0000-0002-2959-176X

Carla Montanari Mergel ${ }^{2}$

https://orcid.org/0000-0001-5774-8173

Patricia dos Santos Costa ${ }^{1}$

https://orcid.org/0000-0003-4640-5882

José Geraldo da Cruz Pradella ${ }^{1}$

https://orcid.org/0000-0002-2902-0983

\section{Gabriel Padilla ${ }^{2}$}

https://orcid.org/0000-0001-8086-3065

${ }^{1}$ Federal University of Santa Catarina, Department of Microbiology, Immunology and Parasitology, Florianópolis, Santa Catarina, Brazil; ${ }^{2}$ University of São Paulo, Institute of Biomedical Sciences, São Paulo, São Paulo, Brazil.

Received: 2018.04.07; Accepted: 2019.05.19.

* Correspondence: diogo.robl@ufsc.br; Tel.: +55-48-37217159

\section{HIGHLIGHTS}

- Selection of endophytic actinomycetes as producers of hemicellulases and related enzymes

- Actinomycetes strains present different glycohydrolases profiles

- The strains produce enzymes against a wide range of plant biomass substrates

\begin{abstract}
Tailor made enzymatic preparation must be design to hydrolyze efficiently plant biomass, once that each plant biomass possesses a distinct cell wall composition. Most of actinomycetes used for plant cell wall degradation are focused on the cellulases and xylanases production. However, a wide range of enzymes must be produced for an efficient degradation of lignocellulose materials. During the last decade several unusual environments were studied to obtain strains that produce glycohydrolases with innovator characteristics. In this context, the present work concerned the selection of endophytic actinomycetes as producers of hemicellulases and related enzymes with different enzymatic profiles, for use in the deconstruction of lignocellulosic biomass. A total of 45 Brazilian
\end{abstract}


Robl, D..; et al.

actinomycetes previously isolated from plants (endophytics) and soil were prospected for hemicellulases and $\beta$-glucosidase production. Four strains highlighted for hemicellulase production (DR61, DR63, DR69 and DR66) and were selected for cultivation under other inductors substrates (xylan and pectin). All strains belong to Streptomyces genera and have their extracts tested for degradation of several hemicellulolytic substrates. The strains presented different glicohydrolyse enzymes profiles mainly for xylans and glucans that can be used for specific formulations of enzymes applied on the biomass deconstruction, principally on sugar cane bagasse.

Keywords: Endophytic actinomycetes; hemicellulases; accessory enzymes

\section{INTRODUCTION}

In biofuels area, the competition to obtain glycohydrolases, mainly cellulases, that hydrolyze efficiently plant biomass cell wall has been extensively studied. Over the years, it has become clear that tailor made enzymatic preparation must be design to hydrolyze efficiently plant biomass, once that each plant biomass possess a distinct cell wall composition [1].

In nature, the lignocellulose materials are decomposed by several microbial glycohydrolases that act on a synergist approach, once that these materials are a recalcitrant substrate. For this reason combinations of enzymes from different sources and types, helped to balance the ideal enzymatic proportion for an efficient hydrolysis. Combinations of cellulolytic enzymes with others glycohydrolases such as xylanases, pectinases, arabinofuranosidase and $\beta$-glucosidase are able to increase the hydrolysis yields in several plant biomass [2-5].

The screening of microorganisms is based on the capacity of bacteria and fungi to produce several compounds with industrial application, e.g enzymes. During the last decade several unusual environments were studied to obtain strains that produce glycohydrolases with different characteristics in plant biomass degradation. Delabona et al. [6] isolated fungi from Amazon forest that produce high activity cellulases and xylanase. Robledo et al. [7] isolated thermophilic fungal strains from maize silage capable to produce thermostable xylanase. Robl et al. [8] screened endophytic fungi strains with a wide range of hydrolytic enzyme profiles to lignocellulose deconstruction.

Endophytic microorganisms showed interest potential for the production of substances with industrial interest such as phytohormones [9], antibiotics [10, 11], antiprotozoal and antitumor molecules [12]. This organism also produce several enzymes such as proteases, amylases, phenol oxidases, lipases, laccases [13-15], and recently it has been shown their potential as lignocellulolytic enzyme producers, e.g cellulases and hemicellulases $[4,5$, 8, 16].

Endophytic microorganisms are ubiquitous in a mutualistic relation [17]. These microorganisms are present within plant tissues and may be able to initiate plant material decomposition process before it becomes dominated by saprophytic species $[18,19]$. The hydrolytic enzyme production by these microorganisms might be important for nutrition during the endophytic stage, but also to compete for substrate during saprophytic stage [8].

Most of the actinomycetes used for plant cell wall degradation are focused on the cellulases and xylanases production [20,21]. Although a wide range of enzymes must be produced for an efficient degradation of lignocellulose materials in nature. In this context, the present work concerns the selection of endophytic actinomycetes as producers of hemicellulases and related enzymes with different enzymatic profiles, for use in the deconstruction of lignocellulosic biomass. 


\section{MATERIAL AND METHODS}

\section{Actinomycetes strains}

Prospection of hemicellulase and related enzymes for plant biomass degradation was performed using an actinomycetes culture collection maintained at the Bioproducts Laboratory (ICB/USP). A total of 45 Brazilian actinomycetes were selected, isolated from Citrus reticulate, Citrus sinensis, Theobroma cacao, Saccharum officinarum, Catharanthus roseus and soil.

\section{Agro-industrial waste materials}

The liquor $(\mathrm{HL})$ used was derived from the hydrothermal pretreatment of sugar cane bagasse and was obtained from Robl et. al [8] study. The sugar cane bagasse was obtained from a local mill (Usina Vale do Rosário, Orlândia, SP, Brazil)The hydrothermal pretreatment sugar cane bagasse process consisted of suspending an amount of bagasse $(10 \% \mathrm{w} / \mathrm{w}$, dry basis) in water and loading it into a laboratory-scale reactor $(7.5 \mathrm{~L}$ total volume, Model 4554, Parr, USA). The temperature was raised from room temperature (25 $\left.{ }^{\circ} \mathrm{C}\right)$ to $190^{\circ} \mathrm{C}$, over a period of $1 \mathrm{~h}$. After 10 minutes, the reactor was cooled to ambient temperature and the pentose-rich liquor $(\mathrm{HL})$ was collected with the aid of a laboratory-scale screen filter (Nutsche filter, POPE Scientific, USA). The soybean bran (SB) was obtained from Agricola (São Carlos, Brazil) and was characterized by Rodriguez-Zuniga et al. [22].

\section{Hemicellulolytic plate assay}

The selection of hemicellulolytic strains was performed by cultivation on solid medium as described by Kasana et al. [23] containing $0.2 \%$ beechwood xylan (Sigma) or liquor $25 \%$ $(\mathrm{v} / \mathrm{v})$. The bacteria strains were first grown on Tryptic Soy Agar (TSA) for 7 days at $29^{\circ} \mathrm{C}$ and then inoculated onto the test media and incubated for $72 \mathrm{~h}$ at $29^{\circ} \mathrm{C}$. The $\mathrm{pH}$ was adjusted to 7.0. The hydrolysis halos were revealed by application of Congo Red (1\%) for 15 minutes, followed by washing with $1 \mathrm{M} \mathrm{NaCl}$ for 10 minutes [23]. The hydrolysis rates were calculated by dividing the diameters of the hydrolysis halos by the diameters of the colony halos.

\section{$\beta$-glucosidase plate assay}

The strains were grown for 5 days in liquid medium [24] with carboxymethylcellulose (CMC, $1 \%)$ as sole carbon source, in $10 \mathrm{~mL}$ tubes $\left(200 \mathrm{rpm}, 29^{\circ} \mathrm{C}, \mathrm{pH} 7.0\right)$. The biomass was separated by centrifugation, and the extract was subjected to an esculin gel diffusion assay (EGDA), as described by Saqib and Whitney [25], for $5 \mathrm{~h}$ at $37^{\circ} \mathrm{C}$. The plate was then placed on ice, and measurement was made of the dark brown zone formed by the action of $\beta$-glucosidase on esculin.

\section{Shake flask cultures}

The composition of the main culture medium was used the medium described by Nascimento et al. [26] : $1 \mathrm{~g} / \mathrm{L}$ de proteose peptone; $0.1 \%(\mathrm{v} / \mathrm{v})$ de tween $80 ; \mathrm{NaNO}_{3} 1.2 \mathrm{~g} / \mathrm{L}$; $\mathrm{KH}_{2} \mathrm{PO}_{4} 3.0 \mathrm{~g} / \mathrm{L} ; \mathrm{K}_{2} \mathrm{HPO}_{4} 6.0 \mathrm{~g} / \mathrm{L} ; \mathrm{MgSO}_{4} .7 \mathrm{H}_{2} \mathrm{O} 0.2 \mathrm{~g} / \mathrm{L} ; \mathrm{CaCl}_{2} 0.05 \mathrm{~g} / \mathrm{L} ; \mathrm{MnSO}_{4} .7 \mathrm{H}_{2} 00.01$ $\mathrm{g} / \mathrm{L} ; \mathrm{ZnSO}_{4} .7 \mathrm{H}_{2} \mathrm{O} 0.001 \mathrm{~g} / \mathrm{L} ; 10 \mathrm{~g} / \mathrm{L}$ carbon source. As carbon source, it was used $10 \mathrm{~g} / \mathrm{L}$ of pretreated delignified sugar cane bagasse (DEB) plus SB, at a 3:1 ratio, once that has been show a potential composition for glycohydrolase liquid prospection [8]. DEB was prepared and characterized by Rocha et al. [27]. The previously selected strains were grown on TSA for 3 days at $29^{\circ} \mathrm{C}$, after which one $0.5 \mathrm{~cm}$ diameter disc was removed from each colony edge, transferred to an Erlenmeyer flask containing $20 \mathrm{~mL}$ of medium, and incubated for 144 $\mathrm{h}$ at $29^{\circ} \mathrm{C}$ and $200 \mathrm{rpm}$. The best four strains were selected for growth using the same conditions and same medium described above, but with the carbon source changed to citrus pectin or beechwood xylan. Samples were removed daily for determination of enzyme activities as described below. The glycohydrolase profile was performed with the enzymatic extracts from the time point that showed the highest glycohydrolase activity over time of culture. 


\section{Enzymatic assays}

Measurement of enzymatic activities (in International Units, IU) was performed using different substrates in order to determine global and single activities. Filter paper activity (FPase) was determined as described by Xiao et al. [28].

All the polysaccharides were purchased from Sigma Aldrich or Megazyme, and were assayed at $0.5 \%$ in a 10 minutes reaction. The polysaccharides used were: Beechwood xylan; Birchwood xylan; Rye arabinoxylan; Wheat arabinoxylan; Sugar beet arabinan; CMC; Barley $\beta$-glucan; Tamarind xyloglucan; Icelandic moss lichenan; Laminarin from Laminaria digitata; Chitosan from shrimp shells; Konjac glucomannan; Carob galactomannan; 1,4 $\beta$-mannan and citrus pectin. CMC was assayed in a 30 minutes reaction. The enzymatic activity was determined from the amount of reducing sugars released from the different polysaccharide substrates, using the DNS method [29] with glucose as standard. The activities of $\beta$-glucosidase, $\beta$-xylosidase, $\beta$-mannosidase, $\alpha$-L-arabinofuranosidase, and cellobiohydrolase II were measured using the respective $p$-nitrophenol residues (pNP) (Sigma-Aldrich, USA). The assays employed $10 \mu \mathrm{L}$ of culture supernatant and $90 \mu \mathrm{L}$ of the respective pNP $(0.5 \mathrm{mM}$, diluted in citrate buffer $)$, and the mixtures were incubated for 10 $\min$ at $50^{\circ} \mathrm{C}$. The reactions were stopped by adding $100 \mu \mathrm{L}$ of $1 \mathrm{M} \mathrm{Na}_{2} \mathrm{CO}_{3}$, and the absorbance was measured at $400 \mathrm{~nm}$ using a Tecan Infinite® 200 instrument (Männedorf, Switzerland). All the assays utilized an epMotion $\AA 5075$ automated pipetting system (Eppendorf) and were performed at $\mathrm{pH} 7.0$ with $50 \mathrm{mM}$ phosphate buffer. One unit of glycohydrolases activity corresponds to $1 \mu \mathrm{mol}$ of monosaccharide or pNP released per minute.

\section{RESULTS}

\section{Plate screening}

The plate screening assay tested 45 actinomycetes for hemicellulases screening on plate assay. Among them 15 strains were not able to grow on media with liquor $(25 \% \mathrm{v} / \mathrm{v})$ and only 23 grew and produced halos in the presence of this waste. All the bacterial strains were able to grow on media containing xylan and 25 hydrolyzed this polysaccharide (Table 1). The sugar cane hydrothermal pretreatment liquor showed the following composition $(\mathrm{g} / \mathrm{L})$ : xylo-oligosaccharides (9.98), xylose (4.70), glucose (0.55), arabinose (0.77), cellobiose (0.0), furfural (1.05), hydroxymethylfurfural (0.18), acetic acid (1.47), formic acid (0.23), and total soluble lignin (3.15). Although this waste present a potential carbon source for hemicellulases screening producers microorganisms, $33 \%$ of the tested strains were inhibited by this substrate. To select actinomycetes that produce $\beta$-glucosidase the EGDA assay was performed. All the strains were able to grow on CMC as sole carborn source. However, when the enzymatic extracts were analyzed, only $11 \%$ actinomycetes were positive for $\beta$-glucosidase production (Table 1). 
Table 1 - Results of the selection of actinomycetes strains using the sum of the hydrolysis ratios for liquor agar and xylan agar, and calculation of the average halos obtained in the esculin gel diffusion assay (EGDA)

\begin{tabular}{|c|c|c|c|c|c|c|}
\hline Strain & Identification & Source & $\begin{array}{c}\text { Hydrolysis } \\
\text { ratio using } \\
\text { liquor } \\
\text { agar }^{b, c}\end{array}$ & $\begin{array}{c}\text { Hydrolysis } \\
\text { ratio using } \\
\text { xylan } \\
\text { agar }^{b, c}\end{array}$ & $\begin{array}{l}\text { Ratio } \\
\text { sum }^{\text {b,c }}\end{array}$ & $\begin{array}{c}\text { EGDA } \\
\text { halo } \\
\text { average } \\
(\mathbf{m m})^{\mathbf{d}, \mathrm{e}}\end{array}$ \\
\hline DR59 & Streptomyces galileus & Soil & 4.80 & 3.37 & 8.17 & - \\
\hline DR60 & Streptomyces sp. & Theobroma cacao & 4.57 & 3.27 & 7.84 & - \\
\hline DR61 & Streptomyce globisporus & C. roseus & 4.22 & 3.21 & 7.43 & - \\
\hline DR62 & Streptomyces sp. & C. sinensis & 3.60 & 3.20 & 6.80 & - \\
\hline DR63 & Streptomyces sp. & Unknown & 2.36 & 4.27 & 6.63 & - \\
\hline DR64 & Streptomyces sp. & C. sinensis & 3.24 & 3.25 & 6.49 & - \\
\hline B6P4 & Streptomyces sp. & S. officinarum & 2.64 & 3.83 & 6.48 & - \\
\hline H4P4 & Streptomyces sp. & S. officinarum & 2.31 & 3.83 & 6.15 & - \\
\hline A10 & Streptomyces sampsonii & C. reticulata & 3.40 & 2.73 & 6.13 & - \\
\hline A82 & Streptomyces pseudogriseolus & S. officinarum & 3.67 & 2.31 & 5.97 & - \\
\hline $\mathrm{A} 12,1(31)$ & Streptomyces sp. & S. officinarum & 1.94 & 3.21 & 5.16 & - \\
\hline A 25 & Streptomyces sp. & C. sinensis & 2.71 & 2.35 & 5.07 & - \\
\hline $\mathrm{H} 4.3$ / C7.3 & Streptomyces sp. & S. officinarum & 1.94 & 2.77 & 4.72 & - \\
\hline G1P1 & S. pseudogriseolus & S. officinarum & 1.88 & 2.77 & 4.66 & - \\
\hline A01 & Streptomyces sp. & C. reticulata & 2.00 & 2.56 & 4.56 & - \\
\hline DR71 & Streptomyces capoamus & Unknown & 2.00 & 2.40 & 4.40 & - \\
\hline DR69 & Streptomyces roseochromogenus & C. roseus & 1.50 & 2.80 & 4.30 & 12.00 \\
\hline DR66 & Streptomyces olindenses & Soil & 2.00 & 2.22 & 4.22 & + \\
\hline $\begin{array}{l}\text { ATCC } \\
31267\end{array}$ & Streptomyces avermitilis & Solo & 1.20 & 3.00 & 4.20 & - \\
\hline A07 & Nocardiopsis sp. & C. sinensis & 1.00 & 3.13 & 4.13 & - \\
\hline G10P4 & Streptomyces macrosporeus & S. officinarum & 1.40 & 2.10 & 3.50 & - \\
\hline A28 & Streptomyces sp. & C. sinensis & 2.44 & 1.00 & 3.44 & - \\
\hline A18 & Streptomyces sp. & C. sinensis & 0.00 & 3.25 & 3.25 & - \\
\hline $\mathrm{A} 03$ & Nocardiopsis sp. & C. reticulata & 0.00 & 3.00 & 3.00 & - \\
\hline $\mathrm{A} 12 \mathrm{P} 2$ & Streptomyces sp. & S. officinarum & 0.00 & 2.93 & 2.93 & - \\
\hline DR67 & Streptomyces lividans & Soil & 0.00 & 2.86 & 2.86 & - \\
\hline DSM46458 & Streptomyces chartresuts & Unknown & 1.60 & 1.00 & 2.60 & - \\
\hline ССТ2398 & Streptomyces rimosus & Unknown & 1.33 & 1.00 & 2.33 & - \\
\hline $\mathrm{A} 04$ & Nocardiopsis sp. & C. reticulata & 0.00 & 2.27 & 2.27 & - \\
\hline $\mathrm{A} 30$ & Streptomyces verne & C. sinensis & 0.00 & 2.05 & 2.05 & - \\
\hline $\mathrm{A} 11 \mathrm{P} 2$ & S. macrosporeus & S. officinarum & 1.00 & 1.00 & 2.00 & - \\
\hline DR65 & Streptomyces sp. & C. sinensis & 1.00 & 1.00 & 2.00 & + \\
\hline $\mathrm{H} 4.3 \mathrm{C} 7.3$ & Streptomyces sp. & S. officinarum & 1.00 & 1.00 & 2.00 & - \\
\hline A08 & Streptomyces sp. & C. reticulata & 1.00 & 1.00 & 2.00 & - \\
\hline A09 & Streptomyces sp. & C. sinensis & 1.00 & 1.00 & 2.00 & - \\
\hline A11 & Nocardiopsis sp. & C. sinensis & 0.00 & 1.56 & 1.56 & - \\
\hline DR70 & Nocardiopsis sp. & C. sinensis & 0.00 & 1.55 & 1.55 & 14.50 \\
\hline DR68 & Nocardiopsis sp. & C. sinensis & 0.00 & 1.00 & 1.00 & + \\
\hline A16 & Nocardiopsis sp. & C. sinensis & 0.00 & 1.00 & 1.00 & - \\
\hline A23 & Streptomyces sp. & C. sinensis & 1.00 & 1.00 & 1.00 & - \\
\hline A32 & Streptomyces sp. & C. sinensis & 0.00 & 1.00 & 1.00 & - \\
\hline $\mathrm{A} 3 \mathrm{P} 1$ & Streptomyces albus & S. officinarum & 0.00 & 1.00 & 1.00 & - \\
\hline A4P1 & Streptomyces pulveraceus & S. officinarum & 0.00 & 1.00 & 1.00 & - \\
\hline F7P4 & Streptomyces akiyoshiensis & S. officinarum & 0.00 & 1.00 & 1.00 & - \\
\hline $\mathrm{H} 4 \mathrm{P} 3$ & Streptomyces tsukiyonensis & S. officinarum & 0.00 & 1.00 & 1.00 & - \\
\hline
\end{tabular}

${ }^{\mathrm{b}} 0.00=$ No growth $;{ }^{\mathrm{c}} 1.00=$ Growth and absence of hydrolysis halo $;{ }^{\mathrm{d}}+=$ Positive unmeasured halo $;{ }^{\mathrm{e}}-=$ No halo. 


\section{Shake flask culturing}

Twelve strains were chosen for shake flask cultivations selection. Eight strains were chosen based on the highest hydrolysis ratio sum and four based on EGDA activity. The DEB was composed of $77.89 \%$ cellulose, $7.09 \%$ hemicellulose, and $16.22 \%$ lignin. The SB consisted of $34 \%$ cellulose, $18.13 \%$ hemicellulose, $9.78 \%$ lignin, and $43.22 \%$ protein. The media prepared using these waste materials can provide a suitable ratio of cellulose and hemicellulose for the synthesis of glycohydrolases, as well as a good source of nitrogen. This composition could induce the production of cellulolytic and hemicellulytic enzymes in several endophytic fungi [8]. All actinomycetes strains presented grow on DEB+SB media at $29^{\circ} \mathrm{C}, 200 \mathrm{rpm}, \mathrm{pH} 7.0$ and enzymatic activities are shown in Figure 1. Low titration of $\beta$-glucosidase, FPase, CMCase and pectinase were detected during 48 and $96 \mathrm{~h}$ of cultivations for all the strains. The low $\beta$-glucosidase production was already present on plate assay. Among 45 strains, 5 showed $\beta$-glucosidase activity and four strains highlighted to xylanase production, DR6, DR66 and DR69, at 48h, and DR63 at 96h.
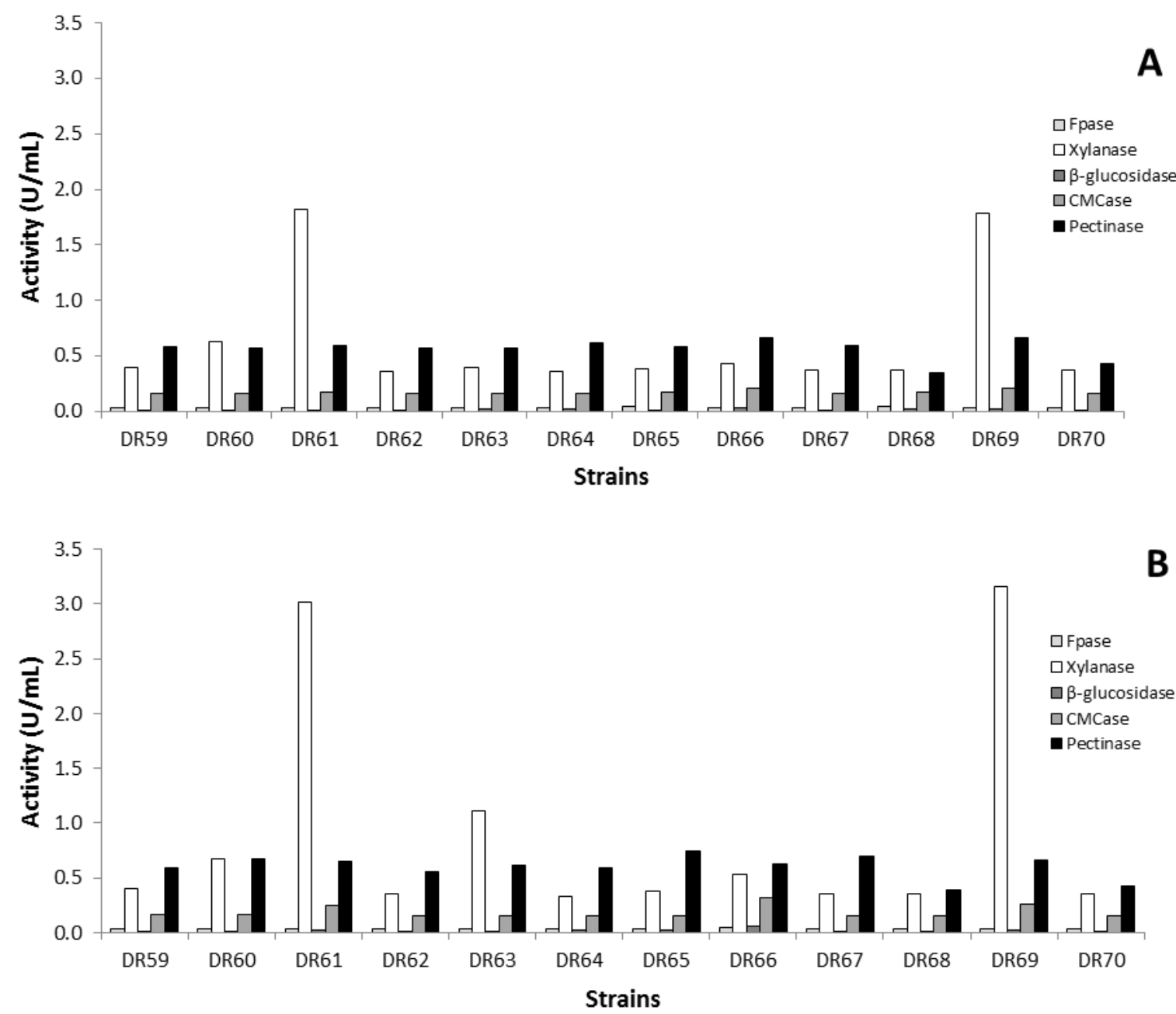

Figure 1 Enzymatic activities of actinomycetes pre-selected strains, grown in shake flasks with DEB+SB (3:1), after $48 \mathrm{~h}(\mathrm{~A})$ and $96 \mathrm{~h}(\mathrm{~B})$.

\section{Glicohydrolyse profile}

In accordance with previous results 4 strains that presented potential for xylanase production (DR61, DR63, DR69 and DR66), for this reason these strains were selected for cultivation under other inductors substrates (xylan and pectin). These strains belong to Streptomyces genera and have their extracts tested for degradation of several hemicellulolytic substrates (Table 2). It was used the extract from the time point that showed 
the highest glycohidrolase activity over time of culture. Low production of cellulose was visualized for the four strains and corroborate with the selection performed. In this way, the absence of $\beta$-glucosidase and cellobiohydrolase activities may be correlated low cellulase production.

High levels of xylanase activity were detected for the 4 strains, although the strains DR63 $(19.26 \mathrm{U} / \mathrm{mL})$ and DR69 $(14.68 \mathrm{U} / \mathrm{mL})$ produced highest titrations. The xylanase production was associated with xylan presence in the media (Table 2) and on hydrolysis a higher hydrolysis against beechwood xylan was presented, probably due to the selection on xylan agar plates. Between branched xylan, rye arabionoxylan was more hydrolyzed for induced xylan enzymes extracts then wheat arabionoxylan.

Some strains, such as DR66 e DR69 were able to produce enzymes with activity to $\beta$-D-glucosil-( $1 \rightarrow 4)-\beta$-D-glucose links from different substrates ( $\beta$-glucan, lichenan and $\mathrm{CMC}$ ), but low affinity on branched glucan (xyloglucan) was visualized. Xylan was also able to induce in the DR63 and DR61 the production of enzymes with activity to $\beta$-D-glucosil-( $1 \rightarrow 3)-\beta$-D-glucose links from laminarin. Pectin presented the same effect in the DR69 strain.

All endophytic strains produced pectinases and its production presented no differences between xylan and pectin used as carbon source for cultivation. The strains DR66 was able to produced enzymes against glucomanan and DR63 produced hydrolytic activity against hetero/homo mannan. No expressive levels of $\alpha$-arabinofuranosidase, $\beta$-xylosidase, $\beta$-manosidase and cellobiohydrolase II were presented under the conditions tested. 
1 Table 2 Glycohydrolases activities $(\mathrm{U} / \mathrm{mL})$ of six selected actinomycetes strains grown on pectin, xylan and DEB.

\begin{tabular}{|c|c|c|c|c|c|c|c|c|c|c|c|c|}
\hline \multirow{2}{*}{$\begin{array}{l}\text { Strain } \\
\text { Carbon source }\end{array}$} & \multicolumn{3}{|c|}{ DR61 } & \multicolumn{3}{|c|}{ DR63 } & \multicolumn{3}{|c|}{ DR66 } & \multicolumn{3}{|c|}{ DR69 } \\
\hline & $\mathrm{BED}+\mathrm{FS}$ & Pectin & Xylan & BED+FS & Pectin & Xylan & BED+FS & Pectin & Xylan & BED+FS & Pectin & Xylan \\
\hline Time (h) & 144 & 96 & 144 & 144 & 144 & 144 & 144 & 96 & 144 & 96 & 144 & 144 \\
\hline Birchwood xylan & 0.73 & 0.53 & 4.66 & 1.22 & 1.00 & 10.99 & 0.76 & 0.53 & 2.56 & 3.16 & 2.52 & 9.98 \\
\hline Beechwood xylan & 1.51 & 0.89 & 8.60 & 1.96 & 1.20 & 19.26 & 1.33 & 0.66 & 4.36 & 3.48 & 1.82 & 14.68 \\
\hline Rye arabinoxylan & 0.99 & 0.28 & 2.26 & 1.31 & 1.70 & 3.74 & 1.18 & 0.53 & 2.15 & 1.80 & 2.05 & 3.27 \\
\hline Wheat arabinoxylan & 0.69 & 0.44 & 0.27 & 0.67 & 0.18 & 0.00 & 0.61 & 0.47 & 0.24 & 0.65 & 0.60 & 0.48 \\
\hline Arabinan & 0.38 & 0.52 & 0.93 & 0.40 & 0.11 & 0.41 & 0.41 & 0.41 & 0.40 & 0.35 & 1.09 & 1.27 \\
\hline CMC & 0.51 & 0.69 & 1.02 & 0.46 & 0.56 & 0.93 & 1.61 & 0.60 & 1.01 & 0.84 & 0.77 & 1.01 \\
\hline$\beta$-glucan & 0.48 & 0.44 & 0.82 & 0.37 & 0.30 & 0.31 & 1.89 & 0.54 & 0.95 & 2.18 & 1.30 & 0.57 \\
\hline Xyloglucan & 0.53 & 0.42 & 0.59 & 0.36 & 0.24 & 0.37 & 0.83 & 0.58 & 0.38 & 0.35 & 1.05 & 0.41 \\
\hline Lichenan & 0.67 & 0.65 & 1.44 & 0.46 & 0.64 & 1.27 & 2.45 & 0.62 & 1.48 & 2.26 & 1.52 & 0.81 \\
\hline Laminarin & 0.43 & 0.50 & 1.16 & 0.41 & 0.73 & 2.39 & 0.47 & 0.43 & 0.40 & 0.40 & 2.22 & 0.62 \\
\hline $1,4 \beta$-mannan & 0.38 & 0.31 & 0.79 & 0.38 & 0.54 & 0.71 & 0.64 & 0.39 & 0.40 & 0.39 & 0.48 & 0.77 \\
\hline Glucomannan & 0.36 & 0.66 & 0.57 & 0.49 & 1.10 & 0.44 & 1.03 & 0.61 & 0.78 & 0.65 & 0.87 & 0.93 \\
\hline Galactomannan & 0.36 & 0.52 & 0.77 & 0.41 & 0.50 & 0.75 & 0.67 & 0.39 & 0.37 & 0.36 & 0.46 & 0.08 \\
\hline Pectin & 0.68 & 0.64 & 0.91 & 0.69 & 0.82 & 1.01 & 0.75 & 0.72 & 0.74 & 0.66 & 0.74 & 0.98 \\
\hline $\begin{array}{l}\text { pNP } \beta \text {-D-xylopyranoside } \\
\text { pNP }\end{array}$ & 0.01 & 0.03 & 0.01 & 0.02 & 0.03 & 0.02 & 0.03 & 0.05 & 0.03 & 0.02 & 0.03 & 0.01 \\
\hline$\beta$-D-mannopyranoside & 0.05 & 0.04 & 0.02 & 0.02 & 0.03 & 0.03 & 0.04 & 0.04 & 0.02 & 0.02 & 0.04 & 0.01 \\
\hline $\begin{array}{l}\text { pNP } \beta \text {-D-cellobioside } \\
\text { pNP }\end{array}$ & 0.01 & 0.04 & 0.01 & 0.01 & 0.04 & 0.07 & 0.03 & 0.04 & 0.04 & 0.03 & 0.06 & 0.07 \\
\hline$\alpha$-L-arabinofuranoside & 0.04 & 0.07 & 0.02 & 0.02 & 0.06 & 0.01 & 0.05 & 0.07 & 0.07 & 0.02 & 0.05 & 0.02 \\
\hline pNP $\beta$-D-glucopyranoside & 0.01 & 0.00 & 0.01 & 0.01 & 0.02 & 0.02 & 0.08 & 0.00 & 0.03 & 0.02 & 0.02 & 0.03 \\
\hline
\end{tabular}




\section{DISCUSSION}

Actinomycetes is an important class of bacteria with industrial interest. The strains used in this work were previously identified by sequencing of 16S DNAr region by Andrielli [30]. Among the 4 strains, only DR66 was isolated from soil and belongs to Streptomyces olindensis species. The strains DR60 and DR69 are endophytics of $C$. roseus and were identified as Streptomyces globisporus and Streptomyces roseochromogenus, respectively. Only the strain DR63 is from an unknown origin and identified as Streptomyces sp.. Even though S. olindensis is capable to produce the antitumor cosmomycin D [31], S. globisporus is known as a producer of $\mathrm{N}$-Acetylmuramidase [32] and S. roseochromogenus of the antibiotic roseomycin [33], none of these species have been described as producer of plant biomass degradation enzymes.

The selection of hemicelullase producer actinomycetes based on plate and liquid were efficient once that it was possible to select strains with different hemicellulolytic profiles. Enzymatic profiles suggested that endophytic strains produced high hemicelullase titration then the soil strain (DR66) and that endophytic strains possess a similar pattern. This corroborate with Book et al. [34], that suggested that free-living soil Streptomyces have not evolved the capacity to rapidly utilize all the components of plant biomass degradation but phytopathogenic strains present CAZy gene content similar to cellulolytic strains which contributes to phytopathogenesis. Even though, endophytic strains does not causes plant diseases, these microorganisms may initiate plant material decomposition process before it becomes dominated by saprophytic species $[18,19]$.

The production of $\beta$-glucosidase is widespread in Streptomyces species $[34,35]$. However, the screening for $\beta$-glucosidase production using de EDGA method lead for false positive selection, once that none of the strains were able to produce detectable amounts of $\beta$-glucosidase by pNP method. Robl et al. [8] used successfully this plate method for fungi $\beta$-glucosidase screening and the plate data corroborated with $\beta$-glucosidase liquid activity.

The formulation of enzymatic cocktails aiming an efficient plant biomass degradation must focus on plant cell wall composition. The mainly component that varies greatly between crops is hemicellulose and lignin. Sugar cane presented mainly xyloglucan and arabinoxylan closely associated with cellulose, whereas pectins, mixed-linkage- $\beta$-glucan (BG), and less branched xylans are strongly bound to cellulose [36]. For this reason this authors proposed an enzymatic hierarchical order to attacked sugar cane cell wall until naked cellulose fiber to become accessible to cellulases. In our work several enzymatic extracts presented potential on the sugar cane cell wall degradation. Bacterial extracts rich in lichenase, $\beta$-glucan, laminarin and pectinase would be useful in the first step to remove the matrix of pectin and $\beta$-glucan. Further extracts rich in endoxylanase activity would be necessary to degraded arabionoxylan. Finally, extracts rich in xyloglucanase would remove the xyloglucan that together with phenolic compounds involves microfibrils of cellulose into macrofibrils. Some enzymes activities were not detected and would be needed to a complete biomass deconstruction, such as $\alpha$-arabinofuranosidase, $\beta$-galactosidase, feruloyl esterase. However, the addition of others microbial enzymatic extracts or recombinant enzymes could overcome this absence.

\section{CONCLUSION}

The present work demonstrated that it is possible to select endophytic strains that can produce glycohydrolases with activities against a wide range of plant biomass substrates. However, biochemical characterization of new reported glycohydrolases producer strains, as well as a bioprocess development of the selected strains in large scale, must be conducted to evaluate the enzyme applicability on the biomass deconstruction, principally on sugar cane bagasse. 
Funding:This research was funded by Fundação de Amparo à Pesquisa do Estado de São Paulo (FAPESP) and Conselho Nacional de Desenvolvimento Científico e Tecnológico (CNPq),grant number 2011/10834-0 and 140154/2011-6.

The authors thank for financial support

Acknowledgments: The authors thank the National Laboratory of Science and Technology of Bioethanol (CTBE) for technical assistance.

Conflicts of Interest: The authors declare no conflict of interest. The funders had no role in the design of the study; in the collection, analyses, or interpretation of data; in the writing of the manuscript, or in the decision to publish the results".

\section{REFERENCES}

1. Robl D, dos Santos Costa P, Rabelo SC, da Silva Delabona P, da Silva Lima DJ, Padilla G, et al. Use of Ascomycete Extracts in Enzymatic Cocktail Formulations Increases Sugar Cane Bagasse Hydrolysis. BioEnergy Res. 2016;9(2):559-65.

2. Goldbeck R, Damásio AR, Gonçalves TA, Machado CB, Paixão DA, Wolf LD, et al. Development of hemicellulolytic enzyme mixtures for plant biomass deconstruction on target biotechnological applications. Appl Microbiol Biotechnol. 2014:1-13.

3. Delabona Pda S, Cota J, Hoffmam ZB, Paixao DA, Farinas CS, Cairo JP, et al. Understanding the cellulolytic system of Trichoderma harzianum P49P11 and enhancing saccharification of pretreated sugarcane bagasse by supplementation with pectinase and alpha-L-arabinofuranosidase. Bioresour technol. 2013 Mar;131:500-7

4. Robl D, da Silva Delabona P, dos Santos Costa P, da Silva Lima DJ, Rabelo SC, Pimentel IC, et al. Xylanase production by endophytic Aspergillus niger using pentose-rich hydrothermal liquor from sugarcane bagasse. Biocatal Biotrans. 2015:1-13.

5. Robl D, dos Santos Costa P, Büchli F, da Silva Lima DJ, da Silva Delabona P, Squina FM, et al. Enhancing of sugar cane bagasse hydrolysis by Annulohypoxylon stygium glycohydrolases. Bioresour Technol. 2015;177:247-54.

6. Delabona PdS, Pirota RDPB, Codima CA, Tremacoldi CR, Rodrigues A, Farinas CS. Using Amazon forest fungi and agricultural residues as a strategy to produce cellulolytic enzymes. Biomass Bioenergy. 2012;37(0):243-50.

7. Robledo A, Aguilar CN, Belmares-Cerda RE, Flores-Gallegos AC, Contreras-Esquivel JC, Montañez JC, et al. Production of thermostable xylanase by thermophilic fungal strains isolated from maize silage. CyTA-J Food. 2016;14(2):302-8.

8. Robl D, Delabona Pda S, Mergel CM, Rojas JD, Costa Pdos S, Pimentel IC, et al. The capability of endophytic fungi for production of hemicellulases and related enzymes. BMC Biotechnol. 2013;13:94.

9. Passari AK, Chandra P, Mishra VK, Leo VV, Gupta VK, Kumar B, et al. Detection of biosynthetic gene and phytohormone production by endophytic actinobacteria associated with Solanum lycopersicum and their plant-growth-promoting effect. Research Microbiol. 2016.

10. Jadulco RC, Koch M, Kakule TB, Schmidt EW, Orendt A, He H, et al. Isolation of pyrrolocins A-C: cis-and trans-decalin tetramic acid antibiotics from an endophytic fungal-derived pathway. J Natural Prod. 2014;77(11):2537-44.

11. Ramos HP, Braun GH, Pupo MT, Said S. Antimicrobial activity from endophytic fungi Arthrinium state of Apiospora montagnei Sacc. and Papulaspora immersa. Braz Arch Biol Technol. 2010;53(3):629-32.

12. Santiago IF, Alves TM, Rabello A, Junior PAS, Romanha AJ, Zani CL, et al. Leishmanicidal and antitumoral activities of endophytic fungi associated with the Antarctic angiosperms Deschampsia antarctica Desv. and Colobanthus quitensis (Kunth) Bartl. Extremoph. 2012;16(1):95-103.

13. Lumyong S, Lumyong P, McKenzie EH, Hyde KD. Enzymatic activity of endophytic fungi of six native seedling species from Doi Suthep-Pui National Park, Thailand. Canad J Microbiol. 2002 Dec;48(12):1109-12. PubMed PMID: 12619825. Epub 2003/03/07. eng.

14. Schulz B, Boyle C. The endophytic continuum. Mycol Research. 2005;109(6):661-86.

15. Carrim AJI, Barbosa EC, Vieira JDG. Enzymatic activity of endophytic bacterial isolates of Jacaranda decurrens Cham.(Carobinha-do-campo). Braz Arch Biol Technol. 2006;49(3):353-9.

16. de Almeida MN, Guimarães VM, Bischoff KM, Falkoski DL, Pereira OL, Gonçalves DS, et al. Cellulases and hemicellulases from endophytic Acremonium species and its application on sugarcane bagasse hydrolysis. Appl Biochem Biotechnol. 2011;165(2):594-610. 
17. Zabalgogeazcoa I, Oleaga A, Pérez Sánchez R. Pathogenicity of endophytic entomopathogenic fungi to Ornithodoros erraticus and Ornithodoros moubata (Acari: Argasidae). Vet Parasitol. 2008;158(4):336-43.

18. Muller MM, Valjakka R, Suokko A, Hantula J. Diversity of endophytic fungi of single Norway spruce needles and their role as pioneer decomposers. Mol Ecol. $2001 \mathrm{Jul} ; 10(7): 1801-10$.

19. Petrini O. Fungal endophytes of tree leaves. Microbial ecology of leaves: Springer; 1991. p. 179-97.

20. de Queiroz Brito-Cunha CC, de Campos ITN, de Faria FP, Bataus LAM. Screening and xylanase production by Streptomyces sp. grown on lignocellulosic wastes. Appl Biochem Biotechnol. 2013;170(3):598-608.

21. Coman G, Bahrim G. Optimization of xylanase production by Streptomyces sp. P12-137 using response surface methodology and central composite design. Ann Microbiol. 2011;61(4):773-9.

22. Rodriguez-Zuniga UF, Farinas CS, Neto VB, Couri S, Crestana S. Aspergillus niger production of cellulases by solid-state fermentation. Pesquisa Agropecuaria Brasileira. 2011 Aug;46(8):912-9.

23. Kasana RC, Salwan R, Dhar H, Dutt S, Gulati A. A rapid and easy method for the detection of microbial cellulases on agar plates using Gram's iodine. Cur Microbiol. 2008;57(5):503-7.

24. Kumar R, Wyman CE. Effect of xylanase supplementation of cellulase on digestion of corn stover solids prepared by leading pretreatment technologies. Bioresour Technol. 2009;100(18):4203-13.

25. Saqib AAN, Whitney PJ. Esculin gel diffusion assay (EGDA): A simple and sensitive method for screening $\beta$-glucosidases. Enzyme Microb Technol. 2006;39(2):182-4.

26. Nascimento R, Coelho R, Marques S, Alves L, Girio F, Bon E, et al. Production and partial characterisation of xylanase from Streptomyces sp. strain AMT-3 isolated from Brazilian cerrado soil. Enzyme Microb Technol. 2002;31(4):549-55.

27. Rocha GJM, Goncalves AR, Oliveira BR, Olivares EG, Rossell CEV. Steam explosion pretreatment reproduction and alkaline delignification reactions performed on a pilot scale with sugarcane bagasse for bioethanol production. Ind Crops Prod. 2012 Jan;35(1):274-9.

28. Xiao Z, Storms R, Tsang A. Microplate-based filter paper assay to measure total cellulase activity. Biotechnol Bioeng. 2004 Dec 30;88(7):832-7.

29. Miller GL. Use of dinitrosalicylic acid reagent for determination of reducing sugar. Anal Chem. 1959 1959;31(3):426-8.

30. ANDRIELLI, FBioprospecção de genes envolvidos na síntese de PKS tipo III em micro-organismos endofítico (2010). Tese - Doutorado em Biotecnologia, Instituto de Ciências Biomédicas, Universidade de São Paulo.

31. Kelso C, Rojas JD, Furlan RL, Padilla G, Beck JL. Characterisation of anthracyclines from a cosmomycin D-producing species of Streptomyces by collisionally-activated dissociation and ion mobility mass spectrometry. European journal of mass spectrometry (Chichester, England). 2009;15(2):73-81.

32. Seo HJ, Shimonishi T, Ohmiya K, Hayashi K. Characterization of $\mathrm{N}$-acetylmuramidase $\mathrm{M}-1$ of Streptomyces globisporus produced by Escherichia coli BL21(DE3)pLysS. J Biosci Bioeng.

33. Ishida N. A basic antibiotic Roseomycin produced by a strain of Streptomyces roseochromogenus, No. 36. Tohoku J exp Medicine. 1953;58(2):153.

34. Book AJ, Lewin GR, McDonald BR, Takasuka TE, Wendt-Pienkowski E, Doering DT, et al. Evolution of High Cellulolytic Activity in Symbiotic Streptomyces through Selection of Expanded Gene Content and Coordinated Gene Expression. PLoS Biol. 2016;14(6):e1002475.

35. Lewin GR, Carlos C, Chevrette MG, Horn HA, McDonald BR, Stankey RJ, et al. Evolution and Ecology of Actinobacteria and Their Bioenergy Applications. Annual Rev Microbiol. 2016;70(1).

36. de Souza AP, Leite DC, Pattathil S, Hahn MG, Buckeridge MS. Composition and structure of sugarcane cell wall polysaccharides: implications for second-generation bioethanol production. BioEnergy Res. 2013;6(2):564-79.

(C) 2018 by the authors. Submitted for possible open access publication under the terms and conditions of the Creative Commons Attribution (CC BY NC) license (https://creativecommons.org/licenses/by-nc/4.0/). 